\title{
Ecology of Vibrio cholerae serogroup 01 in aquatic environments ${ }^{1}$
}

\author{
René J. Borroto ${ }^{2}$
}

\begin{abstract}
The endemic and seasonal nature of cholera depends upon the survival of Vibrio cholerae 01 in a viable but not necessarily culturable state in ecologic niches in aquatic environments during interepidemic periods. To understand the ecology of $\mathrm{V}$. cholerae it is necessary to know which aquatic ecosystems can harbor it and thus contribute to the endemic presence of cholera in Latin America. This article summarizes knowledge about the ecology of V. cholerae 01, specifically, the abiotic and biotic factors that are relevant to the microbe's survival in aquatic environments. This pathogen finds favorable conditions in waters characterized by moderate salinity, high nutrient content, warm temperature, neutral or slightly alkaline $p H$, and the presence of aquatic macrophytes, phytoplankton, zooplankton, fish, mollusks, and crustaceans. These ecologic conditions are typical of estuaries and coastal swamps, and toxigenic V. cholerae 01 is now considered an autochthonous member of the microbial flora of these environments. The microorganism has also shown the ability to colonize freshwater ecosystems in its viable but not necessarily culturable form, if organic or inorganic substrates that favor its survival are available.
\end{abstract}

Vibrio cholerae serogroup 01 consists of the classic and El Tor biotypes, the latter of which is responsible for the seventh cholera pandemic, which is now in progress. These two biotypes comprise the Inaba, Ogawa, and Hikojima serotypes. Epidemic cholera is caused by strains of $V$. cholerae that produce enterotoxin; strains that do not produce the toxin are identified as nonepidemic, although they may cause diarrhea. Vibrios that do not agglutinate serogroup 01 antiserum,

\footnotetext{
This article was published in Spanish in this journal (Vol. 1, No. 1, 1997, pp. 3-8) under the title "La ecología de Vibrio cholerae serogrupo 01 en ambientes acuáticos."

2 Ministry of Science, Technology, and the Environment, Institute of Tropical Geography. Mailing Address: Departamento de Medio Ambiente, Instituto de Geografía Tropical, Ministerio de Ciencias, Tecnología y Medio Ambiente, Calle 11, número 514 entre D y E, Vedado, CP 10400, La Habana, Cuba.
}

known as $V$. cholerae non-01, were previously identified as nonagglutinating or noncholeric vibrios but are now considered $V$. cholerae species. Some non-01 serogroup strains produce toxin and have caused sporadic cases of cholera and small outbreaks of diarrheal disease without causing widespread epidemics (1). The recently discovered serogroup 0139 is an exception, because it has caused epidemics in India (2) and Bangladesh (3).

Until the late 1970s, $V$. cholerae serogroup 01 was believed to be able to survive for only a few hours or days in an aquatic environment (4). This idea has been abandoned because it is now known that the presence of the microorganism in aquatic environments does not depend solely on the extent of fecal contamination. In fact, several studies have revealed that there is no correlation between the presence of fecal coliform bacteria and toxigenic and nontoxigenic strains of $V$. cholerae 01 biotype $\mathrm{El}$ Tor in aquatic environments (5-7). This finding suggests that the pathogenic agent can survive in water that is relatively free of human fecal contamination. Laboratory research $(8,9)$ later confirmed this theory, supporting the hypothesis that the microorganism is an autochthonous member of the microbial flora found in brackish waters typical of estuaries and coastal swamps, as was first suggested by Colwell et al. (10). Toxigenic $V$. cholerae 01 biotype El Tor has also been detected for extended periods in freshwater environments where there is no human fecal contamination $(11,12)$.

In response to environmental stress in aquatic environments, such as low concentrations of nutrients and low temperatures, $V$. cholerae 01 and non- 
01 adopt a viable state that enables them to carry out metabolic functions and form colonies without being culturable (13-16). If favorable environmental conditions return, $V$. cholerae can become culturable again. $V$. cholerae 01 in a viable but nonculturable state has produced clinical symptoms of cholera in volunteers, which confirms that it maintains its pathogenicity in aquatic environments despite the inability of the cells to be cultured (16).

Some experts have suggested that the endemic and seasonal nature of cholera in Bangladesh depends on the presence of the pathogenic agent in a viable but nonculturable state in aquatic ecological niches that serve as reservoirs for the agent between epidemic periods $(13,16-19)$. This article summarizes the ecology of $V$. cholerae 01 on the basis of the abiotic and biotic factors essential for survival of the microbe in aquatic environments.

There is concern that cholera is becoming endemic in Latin America (20). According to the Pan American Health Organization, a seasonal type of cholera has emerged in Ecuador, Peru, and various Central American countries, which suggests that the infection is already endemic (21). To determine which aquatic ecosystems in Latin America can harbor the microorganism and thus contribute to the endemic nature of this disease, it is essential to understand the ecology of $V$. cholerae.

\section{ECOLOGY OF VIBRIO CHOLERAE SEROGROUP 01}

\section{Abiotic factors}

Water. $V$. cholerae, including its toxigenic strains $(5,11,12,22,23)$, has often been isolated from aquatic environments such as bays (5), rivers $(11,12)$, canals (22), ditches (24), and groundwater (23). Cholera transmission takes place primarily through ingestion of water contaminated with the feces or vomitus of patients or, less frequently, with the feces of asymptomatic carriers (1). V. cholerae serogroup 0139 has also been isolated in aquatic environments $(3,25,26)$, and the vibrios of this serogroup are believed to be spread primarily by water (3).

Nutrients. $V$. cholerae 01 is a facultative anaerobe-it relies on respiration when oxygen is present and fermentation when oxygen is absent. $V$. cholerae can grow in media containing carbohydrates, particularly glucose, as well as nitrogen, sulfur, phosphorus, and sodium $(5,8,9)$; to obtain such nutrients, it adheres to sediment (7). $\mathrm{Na}^{+}$is essential for its growth. Two laboratory studies have revealed that toxigenic strains of $V$. cholerae 01 biotype El Tor need $\mathrm{Na}^{+}$to survive in the absence of other nutrients and to grow more rapidly in the presence of other nutrients $(9,27)$. It was determined that the need for $\mathrm{Na}^{+}$could not be met by substituting the alkali metals $\mathrm{Li}^{+}$ and $\mathrm{K}^{+}(27)$. However, when $\mathrm{Na}^{+}$is available, addition of the alkaline earth metals $\mathrm{Ca}^{2+}$ and $\mathrm{Mg}^{2+}$ has been found to help prolong the survival of V. cholerae (9).

Another study found that $V$. cholerae 01 strains of clinical origin (of the classic and El Tor biotypes) could survive up to 12 days in unchlorinated water when ferric oxide $\left(\mathrm{Fe}_{2} \mathrm{O}_{3}\right)$ was present (28). The microorganism produces vibriobactin, which is a siderophore capable of chelating the iron and then solubilizing it and transporting it to the cell. The authors of the report concluded that iron is an important factor in the epidemiology of cholera.

Salinity. In a laboratory study conducted by Singleton et al. (8), it was determined that, in the absence of nutrients, the ideal salinity for growth of toxigenic $V$. cholerae 01 biotype $\mathrm{El}$ Tor is 25 parts per 1000 . $V$. cholerae can grow in aquatic environments of high salinity (45 parts per 1000 ) if it receives $500 \mu \mathrm{g}$ or more of tryptone as a substrate. Another laboratory study conducted by the same researchers (27) found that the microorganism prefers moderate salinity (from 15 to 25 parts per 1000 ) and that it can grow in systems with $1 \%$ (weight/volume) tryptone with or without $\mathrm{NaCl}$. This finding indicates that tryptone has sufficient $\mathrm{Na}^{+}$to guarantee growth of the microbe. This study supports the hypothesis that toxigenic $V$. cholerae 01 is an autochthonous member of estuarine microbial flora.

Miller et al. (9) ascertained that toxigenic $V$. cholerae 01 biotype El Tor is able to survive without nutrients in warm water with a salinity of 2.5 to 30 parts per 1000 but that the optimal salinity for survival is 20 parts per 1000 . Toxigenic and nontoxigenic strains of $V$. cholerae 01 biotype El Tor have been isolated from brackish waters of estuaries and coastal swamps $(5,6,22,24)$. Tamplin and Colwell (29) found that, for $V$. cholerae 01 to produce toxins, the optimal salinity ranges between 20 and 25 parts per 1000 . The pathogenic microorganism is nevertheless capable of colonizing freshwater ecosystems. Singleton et al. (27) concluded that the presence of $V$. cholerae in aquatic environments is not limited to estuaries, because salinity requirements can be fulfilled through an adequate nutrient concentration in freshwater environments. Miller et al. (19) found that the microbe maintained its ability to produce toxins in the laboratory after 64 days of exposure to low salinity. Others have reported that the microbe is able to survive in freshwater environments for extended periods $(11,12)$.

In Queensland, Australia, toxigenic $V$. cholerae 01 biotype El Tor was detected for two months in a river with no human fecal contamination (11). The authors of that study concluded that the microorganism is able not only to survive but also to multiply in river water. Another study carried out from 1977 to 1984 (12) detected toxigenic $V$. cholerae biotype $\mathrm{El}$ Tor in 11 rivers in Queensland, again in the absence of human fecal contamination. The researchers concluded that the microorganism is able to survive and multiply in rivers. Islam et al. (17) suggested that freshwater impoundments in an endemic area of Bangladesh could become reservoirs for $V$. cholerae 01 . 
Temperature. The ideal growth temperature for toxigenic $V$. cholerae 01 biotype El Tor varies between 30 and $37{ }^{\circ} \mathrm{C}(5,9,27)$. In samples collected from three rivers in Queensland between 1977 and 1980, toxigenic $V$. cholerae 01 biotype El Tor was isolated more frequently in the summer than in the winter (12).

In a study carried out in Kent, United Kingdom, most environmental isolations of nontoxigenic strains of $V$. cholerae 01 biotype $\mathrm{El}$ Tor occurred during the summer (24). In the frigid waters $\left(12{ }^{\circ} \mathrm{C}\right)$ of the Peruvian side of Lake Titicaca, which is over $3000 \mathrm{~m}$ above sea level, $V$. cholerae 01 biotype El Tor (of unresearched toxigenicity) was isolated only occasionally and in very low concentrations (30).

Acidity. Toxigenic $V$. cholerae 01 biotype El Tor can tolerate alkaline environments and is very sensitive to acidity $(9,19)$. A laboratory study by Miller et al. (9) revealed that the optimal $\mathrm{pH}$ for survival in $25^{\circ} \mathrm{C}$ water is between 7 and 8.5 when salinity is moderate and between 7.5 and 9 when salinity is low.

Sunlight. Because toxigenic $V$. cholerae 01 shows little resistance to ultraviolet radiation, a study has been proposed to research the use of sunlight for disinfecting drinking water in the Andes (31).

\section{Biotic factors}

Aquatic macrophytes. Toxigenic $V$. cholerae 01 biotype $\mathrm{El}$ Tor has been isolated from macrophytes in both seawater and fresh water (32-34). In a study carried out in Bangladesh by Spira et al. (32), toxigenic $V$. cholerae 01 biotype El Tor was isolated from the roots of Eichhornia crassipes, a freshwater macrophyte also known as water hyacinth. The authors observed that adhesion of the microorganism to the plant roots favors its survival.

Under laboratory conditions, Islam et al. (33) ascertained that two toxi- genic strains of serogroup 01 biotype El Tor survived for longer periods when they were attached to the freshwater macrophyte Lemna minor than when they were suspended in the water where the plants had been floating. The pathogenic agent secretes the enzyme mucinase, which is considered to be one of the factors responsible for the virulence of $V$. cholerae (35) and which degrades the cellular mucilage of plants, including L. minor (33). Islam et al. have suggested that aquatic plants could be environmental reservoirs of the microbe through either a nonspecific association or a commensal relationship (33).

\section{Phytoplankton and zooplankton.} $V$. cholerae serogroup 01 targets species of sea- and freshwater phytoplankton and zooplankton to which it adheres $(13,36-40)$. In a laboratory study, Huq et al. (39) researched the ecological association between $V$. cholerae 01 and planktonic copepods from the Chesapeake Bay in the United States of America and from the Buriganga River in Bangladesh. The species of planktonic copepods collected from the Chesapeake Bay were Acartia tonsa, Eurytemora affinis, and Scottolana spp. In the samples taken from the Buriganga River, the two predominant species of planktonic copepods were not identified. Two vibrio strains were used: one of clinical origin (classic biotype) and one isolated from a river in Dacca, Bangladesh (El Tor biotype). The researchers noted that $V$. cholerae 01 colonized primarily the oral regions and egg sacks of the planktonic copepods. Their results suggest that reproduction of vibrios takes place in the egg sack, the digestive system, and the chitinous exoskeleton of copepods. The pathogenic agent secretes chitinase, an enzyme that enables it to digest chitin and use it as a source of nutrients (41). Adhesion to chitinous surfaces provides more resistance to moderate levels of acidity (42) and to low temperatures (43). Huq et al. concluded that oviposition and expulsion of fecal material by planktonic copepods can expedite dissemination and reproduction of the pathogenic microorganism in aquatic environments (39).

A laboratory study by Tamplin et al. (37) in Bangladesh indicated that five strains of $V$. cholerae 01 of clinical origin (three of the classic biotype and two of the El Tor biotype) adhered primarily to the exoskeleton of copepods (Acartia sp., Acartia chilkaensis, Acartia sewelli, and Cyclops sp.), cladocerans (Bosmina sp., Ceriodaphnia sp., Diaphanosoma sp., and Bosminopsis sp.), and rotifers (Brachionus sp.). They were also able to attach to two species of green algae (Volvox sp. and Pediastrum simplex) and to two species of bluegreen algae (Spirulina sp. and unicellular cyanobacteria).

Islam et al. (36) found that toxigenic $V$. cholerae 01 biotype El Tor had a greater tendency to attach to the green alga Rhizoclonium fontanum than to the following four freshwater species: a blue-green alga (Anabaena variabilis), a green alga (Cladophora sp.), an aquatic moss (Fontinalis antipyretica), and an aquatic angiosperm (Elodea canadensis). It has been suggested that the prolonged survival of toxigenic $V$. cholerae when attached to $R$. fontanum could indicate its ability to derive nutrients from the extracellular products released by this species.

In Bangladesh, toxigenic $V$. cholerae has been isolated in cultures from water samples collected from environmental reservoirs during epidemic periods but not between epidemics (44). However, the fluorescent monoclonal antibody method, which is capable of detecting viable but nonculturable vibrios, revealed strains of $V$. cholerae 01 (of unresearched biotype and toxigenicity) in $64 \%$ of plankton specimens collected from water at the mouth of the Ganges and Meghna rivers in Bangladesh, even during the interepidemic periods (13). In contrast, when culture methods were used, only $0.3 \%$ of plankton specimens yielded positive results. That study revealed the presence of $V$. cholerae 01 in the region's aquatic environments throughout the year. Although the surfaces of copepods were the most densely colonized, $V$. cholerae 01 was 
also found attached to species of rotifers, cladocerans (Daphnia), Volvox, and Desmida. The authors hypothesized that culturable vibrios in aquatic environments adhere to plankton to withstand the seasonal changes in temperature, salinity, $\mathrm{pH}$, and nutrient concentration and that they enter a nonculturable state for a given period as a way to adapt to such changes. According to this hypothesis, once favorable growth conditions return, $V$. cholerae 01 can again adopt its culturable state and pose the threat of an epidemic if certain plankton blooms contribute to its reproduction.

Undetermined biotypes of $V$. cholerae 01 of unknown toxigenicity have been detected in the viable but nonculturable state in phytoplankton specimens of the species Anabaena variabilis, a cyanobacteria collected from a pond in Dacca, Bangladesh. No association has been observed with species of genera such as Euglena and Phacus (38). Islam et al. hypothesized that $V$. cholerae 01 uses extracellular products released from $A$. variabilis for nutrition and that the availability of salts on the mucilaginous surface of this bluegreen alga enables $V$. cholerae 01 to survive for prolonged periods in freshwater environments (45). They also proposed that photosynthesis by $A$. variabilis supplies oxygen for the aerobic respiration of $V$. cholerae 01 and that the microorganism, in turn, is the source of carbon dioxide for $A$. variabilis. The authors concluded that $V$. cholerae 01 in a viable but nonculturable state is associated with $A$. variabilis and, possibly, with other species of blue-green algae with a mucilaginous surface, which could serve as ecological niches in estuaries and freshwater ecosystems.

Fish, mollusks, and crustaceans. In the United States, toxigenic $V$. cholerae 01 biotype $\mathrm{El}$ Tor has been isolated from shrimp and crabs in Louisiana (22) as well as from oysters and the intestines of fish caught in Mobile Bay, Alabama (46). Nontoxigenic strains of serogroup 01 biotype El Tor have been isolated from oysters (Crassostrea virginica) found in estuarine waters in the state of Florida (6). In 1991, $V$. cholerae 01 (of unresearched toxigenicity) was detected in fish and mollusks in the coastal waters of Lima, Peru (30). The chitinous surface of the crustaceans provides a suitable substrate for reproduction of the pathogenic microbe. Epidemiologic studies (47-49) revealed an association between the incidence of cholera and the consumption of fish and other raw or undercooked seafood.

Aquatic birds. In the United States, toxigenic $V$. cholerae 01 biotype El Tor was isolated in 1986 and 1987 from the feces of great blue herons (Ardea herodias) in Colorado and Utah but not from water samples collected from the birds' habitat (50). The authors concluded that such aquatic birds could be carriers of the pathogenic agent and contribute to its overall dissemination.

\section{CONCLUSIONS}

Some experts believe that to properly control cholera it is necessary to prevent humans from coming into contact with the natural reservoirs of toxigenic $V$. cholerae 01 (51). This implies the ability to identify aquatic environments where abiotic and biotic ecological conditions enable the microorganism to survive between epidemics.

The optimal conditions for the survival and growth of toxigenic $V$. cholerae 01 are aquatic environments rich in nutrients and with moderate salinity, warm temperatures, and neutral or slightly alkaline $\mathrm{pH}$. Such conditions are typical of estuaries and coastal swamps in equatorial, tropical, and subtropical regions, where many species of phytoplankton and zooplankton, fish, mollusks, and crustaceans thrive $(52,53)$. The ecological niche of $V$. cholerae 01 is currently considered to exist in estuarine waters, where it can survive even in the absence of human fecal contamination.

With the environmental stress that accompanies decreases in nutrient availability and salinity, toxigenic $V$. cholerae 01 assumes a viable state that allows it to perform metabolic functions and to form colonies without being culturable. In this viable but nonculturable state, concentrations of the microorganism adhere to the surfaces of various species of aquatic macrophytes, phytoplankton, and zooplankton. Through such ecological associations, $V$. cholerae can survive between epidemic periods without sacrificing its toxigenicity (34), even in freshwater ecosystems. This phenomenon contributes to the endemic nature of cholera.

In general, concentrations of $V$. cholerae 01 in waters without human fecal contamination are considerably lower than the amount required to produce cholera. Nevertheless, it is possible that, during seasonal blooms of phytoplankton and zooplankton, $V$. cholerae 01 concentrations associated with these substrates increase to the point of causing disease $(13,16,40)$. In the future, additional research will be needed to determine whether $V$. cholerae serogroup 0139 is also associated with species of plankton, macrophytes, and aquatic macrofauna as a survival strategy.

Given the endemic nature of cholera in some Latin American countries, field and laboratory studies are necessary to define and identify the aquatic reservoirs that favor survival of toxigenic $V$. cholerae 01 between epidemic periods. Research is needed to determine whether its association with phytoplankton, zooplankton, and macrophytes of the aquatic ecosystems of this hemisphere is indiscriminate or whether, on the contrary, it exhibits a preference for certain species of bluegreen algae and planktonic copepods, as suggested by findings from Bangladesh. It is also necessary to determine both the geographic location of waters that harbor reservoirs of toxigenic $V$. cholerae 01 and the communities that use that water for consumption, bathing, fishing, and other activities.

Finally, elimination of endemic cholera also depends on the progress made in eradicating extreme poverty 
and, in particular, improving services for drinking water supply, excreta disposal, and wastewater treatment.

Acknowledgments. The author wishes to thank Bohumil Drasar, Paul
Epstein, Roger Glass, Richard Guerrant, Anwarul Huq, David Sack, Mohammad Sirajul Islam, and Mark Tamplin for the kind contribution of their recent articles; María Isabel González González for her review and suggestions; Elibel Atala Portes and

\section{REFERENCES}

1. Benenson A, ed. Control of communicable diseases in man. 15th ed. Washington, DC: American Public Health Association; 1990.

2. Ramamurthy T, Grag S, Sharma R, et al. Emergence of a novel strain of Vibrio cholerae with epidemic potential in southern and eastern India. Lancet 1993;341:703-704.

3. Islam MS, Hasan M, Miah M, Yunus M, Zaman K, Albert M. Isolation of Vibrio cholerae 0139 synonym Bengal from the aquatic environment in Bangladesh: implications for disease transmission. Appl Environ Microbiol 1994;60:1684-1686.

4. Felsenfeld O. Review of recent trends in cholera research and control with an annex on the isolation and identification of cholera vibrios. Bull World Health Organ 1966;34:161-196.

5. Colwell R, Seidler R, Kaper J, et al. Occurrence of Vibrio cholerae serotype 01 in Maryland and Louisiana estuaries. Appl Environ Microbiol 1981:41:555-558.

6. Hood M, Ness G, Rodrick G. Isolation of Vibrio cholerae serotype 01 from the eastern oyster, Crassostrea virginica. Appl Environ Microbiol 1981;41:559-560.

7. Hood M, Ness G. Survival of Vibrio cholerae and Escherichia coli in estuarine waters and sediments. Appl Environ Microbiol 1982;43: 578-584.

8. Singleton F, Attwell R, Jangi M, Colwell R. Influence of salinity and organic nutrient concentration on survival and growth of Vibrio cholerae in aquatic microcosms. Appl Environ Microbiol 1982;43:1080-1085.

9. Miller C, Drasar B, Feachem R. Response of toxigenic Vibrio cholerae 01 to physicochemical stress in aquatic environments. J Hyg (Lond) 1984;93:475-495.

10. Colwell R, Kaper J, Joseph S. Vibrio cholerae, Vibro parahaemolyticus, and other vibrios: occurrence and distribution in Chesapeake Bay. Science 1977;198:394-396.

11. Rogers R, Cuffe R, Cossins Y, Murphy D, Bourke A. The Queensland cholera incident of 1977; II, the epidemiological investigation. Bull World Health Organ 1980;58:665-669.

12. Bourke A, Cossins Y, Gray B. Investigation of cholera acquired from the riverine environment in Queensland. Med J Aust 1986;144: 229-234.

13. Huq A, Colwell R, Rahman R, et al. Detection of Vibrio cholerae 01 in the aquatic environment by fluorescent-monoclonal antibody and culture methods. Appl Environ Microbiol 1990;56:2370-2373.
14. Colwell R, Brayton P, Grimes D, Roszak D, Huq A, Palmer L. Viable, but non-culturable Vibrio cholerae and related pathogens in the environment: implication for release of genetically engineered microorganisms. Biotechnology 1985;3:817-820.

15. Brayton P, Tamplin M, Huq A, Colwell R. Enumeration of Vibrio cholerae 01 in Bangladesh waters by fluorescent-antibody direct viable count. Appl Environ Microbiol 1987;53: 2862-2865.

16. Colwell R, Huq A. Vibrios in the environcholerae. In: Wachsmuth IK, Blake P, Olsvik O, eds. Vibrio cholerae and cholera: molecular to global perspectives. Washington, DC: American Society for Microbiology; 1994:117-133.

17. Islam MS, Drasar BS, Sack RB. The aquatic environment as a reservoir of Vibrio cholerae: a review. J Diarrhoeal Dis Res 1993;11:197-206.

18. Miller C, Feachem R, Drasar BS. Cholera epidemiology in developed and developing countries: new thoughts on transmission, seasonality, and control. Lancet 1985;i:261-263.

19. Miller C, Drasar BS, Feachem R, Hayes R. The impact of physico-chemical stress on the toxigenicity of Vibrio cholerae. I Hyg (Lond) 1986;96:49-57.

20. Weil $\mathrm{O}$, Berche P. The cholera epidemic in Ecuador: towards an endemic in Latin America. Rev Epidemiol Sante Publique 1992;40: 144-145.

21. Organización Panamericana de la Salud. La situación del cólera en las Américas. Bol Epidemiol (OPS) 1994;15:13-16.

22. Blake PA, Allegra DT, Snyder JD, et al. Cholera: a possible focus in the United States. N Engl J Med 1980;302:305-309.

23. Tauxe R, Holmberg S, Dodin A, Wells J, Blake P. Epidemic cholera in Mali: high mortality and multiple routes of transmission in a famine area. Epidemiol Infect 1988;100:279-289.

24. Lee J, Bashford D, Donovan T, Furniss A, West P. The incidence of Vibrio cholerae in water, animals, and birds in Kent, England. J Appl Bacteriol 1982;52:281-291.

25. Islam MS, Hasan MK, Miah MA, et al. Isolation of Vibrio cholerae 0139 Bengal from water in Bangladesh [letter to the editor]. Lancet 1993;342:430.

26. Shimada T, Nair GB, Deb BC, Albert MJ, Sack RB. Outbreak of Vibrio cholerae non-01 in India and Bangladesh. Lancet 1993;341:1346-1347.

27. Singleton F, Attwell R, Jangi M, Colwell R. Effects of temperature and salinity on Vibrio ment: viable but non-culturable Vibrio
Ileana Herrera for their extensive review; and María Josefa Sánchez, Laura Bravo, Ana Isabel Fernández, and Anisia Silva for conceptual clarifications. cholerae growth. Appl Environ Microbiol 1982; 44:1047-1058.

28. Patel M, Isaäcson $M$. The effect of iron on the survival of Vibrio cholerae 01 in dechlorinated tap water. Trans $R$ Soc Trop Med Hyg 1994; 88:296-297.

29. Tamplin M, Colwell R. Effects of microcosm salinity and organic substrate concentration on production of Vibrio cholerae enterotoxin. Appl Environ Microbiol 1986;52:297-301.

30. Tamplin M, Carrillo C. Environmental spread of Vibrio cholerae in Peru [letter to the editor]. Lancet 1991;338:1216-1217.

31. Tauxe R, Blake P. Epidemic cholera in Latin America. JAMA 1992;267:1388-1390.

32. Spira W, Huq A, Ahmed Q, Saeed Y. Uptake of Vibrio cholerae biotype El Tor from contaminated water by water hyacinth (Eichhornia crassipes). Appl Environ Microbiol 1981;42: 550-553.

33. Islam MS, Drasar BS, Bradley DJ. Survival of toxigenic Vibrio cholerae 01 with a common duckweed, Lemna minor, in artificial aquatic ecosystems. Trans R Soc Trop Med Hyg 1990; 84:422-424.

34. Islam MS, Drasar BS, Sack RB. The aquatic flora and fauna as reservoirs of Vibrio cholerae: a review. J Diarrhoeal Dis Res 1994;12:87-96.

35. Schneider D, Parker C. Purification and characterization of the mucinase of Vibrio cholerae. J Infect Dis 1982;145:474-482.

36. Islam MS, Drasar BS, Bradley DJ. Attachment of toxigenic Vibrio cholerae 01 to various freshwater plants and survival with a filamentous green alga, Rhizoclonium fontanum. J Trop Med Hyg 1989;92:396-401.

37. Tamplin M, Gauzens A, Huq A, Sack R, Colwell R. Attachment of Vibrio cholerae serogroup 01 to zooplankton and phytoplankton of Bangladesh waters. Appl Environ Microbiol 1990;56:1977-1980.

38. Islam MS, Miah MA, Hasan MK, Sack RB, Albert MJ. Detection of non-culturable Vibrio cholerae 01 associated with a cyanobacterium from an aquatic environment in Bangladesh [short report]. Trans $R$ Soc Trop Med Hyg 1994;88:298-299.

39. Huq A, Small E, West P, Huq M, Rahman R Colwell R. Ecological relationships between Vibrio cholerae and planktonic crustacean copepods. Appl Environ Microbiol 1983;45: 275-283.

40. Huq A, West P, Small E, Huq M, Colwell R Influence of water temperature, salinity, and $\mathrm{pH}$ on survival and growth of toxigenic Vibrio 
cholerae serovar 01 associated with live copepods in laboratory microcosms. Appl Environ Microbiol 1984;48:420-424.

41. Nalin D. Cholera, copepods, and chitinase. Lancet 1976;ii:958.

42. Nalin D, Daya V, Reid A, Levine M, Cisneros L. Adsorption and growth of Vibrio cholerae on chitin. Infect Immun 1979;25:768-770.

43. Amako K, Shimodori S, Imoto T, Miake S, Umeda A. Effects of chitin and its soluble derivatives on survival of Vibrio cholerae 01 at low temperature. Appl Environ Microbiol 1987;53:603-605.

44. McCormack W, Islam M, Fahimuddin M, Mosley W. Endemic cholera in rural East Pakistan. Am J Epidemiol 1969;89:393-404.

45. Islam MS, Drasar BS, Sack RB. Probable role of blue-green algae in maintaining endemicity and seasonality of cholera in Bangladesh: a hypothesis. J Diarrhoeal Dis Res 1994;12: 245-246.

46. DePaola A, Capers G, Motes M. Isolation of Latin American epidemic strain of Vibrio cholerae 01 from US Gulf Coast. Lancet 1992;339:624.

47. Baine W, Mazzotti M, Greco D, et al. Epidemiology of cholera in Italy, 1973. Lancet 1974;ii:1370-1374.

48. McIntyre RC, Tira T, Flood T, Blake P. Modes of transmission of cholera in a newly infected population on an atoll: implications for control measures. Lancet 1979;i:311-314.

49. Salmaso S, Greco D, Bonglifio B, et al. Recurrence of pelecypod-associated cholera in Sardinia. Lancet 1980;ii:1124-1127.

50. Ogg J, Ryder R, Smith H Jr. Isolation of Vibrio cholerae from aquatic birds in Colorado and Utah. Appl Environ Microbiol 1989;55:95-99.
51. Glass R, Black R. The epidemiology of cholera. In: Barua D, Greenough W III, eds. Cholera. New York: Plenum Medical Company; 1992:129-154.

52. Nebel B, Wright R. Environmental science: the way the world works. 4 th ed. Englewood Cliffs, New Jersey: Prentice Hall; 1993.

53. Miller GT Jr. Environmental science: sustaining the earth. 3rd ed. San Francisco: Wadsworth Publishing Company; 1991.

Manuscript received on 18 December 1995. Revised version accepted for publication on 10 July 1996.

RESUMEN El carácter endémico y estacional del cólera depende de la supervivencia de Vibrio cholerae serogrupo 01 en estado viable, pero no necesariamente cultivable, en nichos ecológicos localizados en ambientes acuáticos durante períodos interepidémicos. Para comprender la ecología de $V$. cholerae es preciso conocer los ecosistemas acuáticos que pudieran albergarlo y contribuir a la presencia endémica del cólera en América Latina. El presente artículo tiene por objetivo presentar, en términos resumidos, la ecología de $V$. cholerae 01 organizada según los factores abióticos y bióticos que inciden en la supervivencia del microbio en ambientes acuáticos. Este agente patógeno encuentra condiciones favorables en aguas caracterizadas por niveles moderados de salinidad, un alto contenido de nutrientes, temperaturas cálidas, un $\mathrm{pH}$ neutro o ligeramente alcalino y la presencia de macrófitas acuáticas, fitoplancton, zooplancton, peces, moluscos y crustáceos. Estas condiciones ecológicas son propias de los ecosistemas acuáticos de estuarios y pantanos costeros, de cuya flora microbiana $V$. cholerae 01 toxígeno se considera actualmente un miembro autóctono. Este microorganismo también se ha mostrado capaz de colonizar ecosistemas de agua dulce en su forma viable, aunque no necesariamente cultivable, si encuentra sustratos orgánicos e inorgánicos que favorezcan su supervivencia. 